\title{
Intravenous immunoglobulin in treatment of Clostridium difficile colitis
}

\author{
Lokesh Shahani, ${ }^{1}$ Janak Koirala² \\ 1Department of Internal Medicine, Southern Illinois University School of Medicine, Springfield, Illinois, USA; \\ ${ }^{2}$ Division of Infectious Diseases, Southern Illinois University School of Medicine, Springfield, Illinois, USA
}

Correspondence toDr Lokesh Shahani, lokesh83@hotmail.com

\begin{abstract}
Summary
Clostridium difficile infection is the most common infectious cause of healthcare-acquired diarrhoea. Severe infections cause therapeutic challenges for healthcare providers. Various novel treatment modalities are currently being explored for treatment of severe disease. The authors report a 70-year-old female who presented to the emergency room with 1 week history of fever, watery diarrhoea, diffuse abdominal pain and weakness. C difficile toxin was detected in the stool and abdominal CAT scan showed extensive colonic wall thickening. The patient was started on intravenous metronidazole along with oral vancomycin. Due to the severity of the infection the patient was given intravenous immunoglobin for 4 consecutive days. The patient had vast improvement in her clinical symptoms with resolution of the multi-organ system failure. It is currently considered that the predominant intravenous immunoglobin's mechanism of action is through binding and neutralisation of toxin $\mathrm{A}$ by $\lg \mathrm{G}$ antitoxin $\mathrm{A}$ antibodies.
\end{abstract}

\section{BACKGROUND}

Clostridium difficile is a gram-positive, anaerobic, spore forming, rod-shaped bacterium and has been linked to antibiotic associated diarrhoea. $C$ difficile infection is the most common infectious cause of healthcare-acquired diarrhoea. ${ }^{1}$ The incidence of this infection has sharply increased in the previous decade and so has the associated death rate and burden on healthcare cost. $C$ difficile has also become more refractory to standard therapy and more severe, as indicated by increased rates of toxic megacolon, disease requiring colectomy, associated shock, or death. ${ }^{2} 3$ Severe infections cause difficult management issues for patients and therapeutic challenges for their healthcare providers. Various novel treatment modalities are currently being explored for treatment of the severe disease. We discuss a case where intravenous immunoglobulin (IVIG) was used in the treatment of severe colitis.

\section{CASE PRESENTATION}

A 70-year-old female presented to the emergency room with a 1 week history of fever, watery diarrhoea, diffuse abdominal pain and weakness. The patient denied symptoms of melena or haematochezia. She denied having any associated nausea or vomiting. The patient had been successfully treated for a urinary tract infection with levofloxacin, a week prior to the onset of her symptoms. Medical history included hypertension and an episode of $C$ difficle colitis 5 months prior to this presentation. The patient was staying independently and denied any recent sick contacts or contact with pets. She denies any alcohol, nicotine or illicit drug use.

Physical examination on arrival revealed a patient with marked respiratory distress. She was febrile on presentation and hypotensive with blood pressure of $84 / 56 \mathrm{~mm}$
$\mathrm{Hg}$. The patient was tachypneic with respiratory rate of 32 per min. Patient had a distended abdomen with tenderness present in the lower quadrants. She had hypoactive bowel sounds. Cardiovascular and respiratory system auscultatory findings were normal.

\section{INVESTIGATIONS}

The patient was started on intravenous fluids and dopamine to provide adequate vasopressor support. She was intubated and ventilator support was provided considering her respiratory distress. Routine laboratory investigation revealed elevated white blood cell count of 36980 cells/ $\mathrm{mm}^{3}$ with absolute neutrophil count of 34020 cells $/ \mathrm{mm}^{3}$. Patient had new onset renal insufficiency with serum creatinine of $1.9 \mathrm{mg} / \mathrm{dl}$ and glomerular filtration rate of $26 \mathrm{ml} /$ $\mathrm{min} / 1.73$ sq.m. Considering the history of $C$ difficle colitis and recent antibiotics use with the past 2 weeks, $C$ difficle infection was considered. The patient was initially started on the standard regimen of metronidazole $500 \mathrm{mg}$ intravenously every $8 \mathrm{~h}$ and oral vancomycin $500 \mathrm{mg}$ every $6 \mathrm{~h}$. A $C$ difficle toxin PCR which detects the $C$ difficle toxin $B$ gene in the stool specimen was positive. CAT scan of the abdomen showed extensive colonic wall thickening involving the ascending colon, hepatic flexure, transverse colon and the splenic flexure.

\section{DIFFERENTIAL DIAGNOSIS}

Ischaemic, inflammatory or infectious causes of colitis were considered. With detection of $C$ difficle toxin in the stool a diagnosis of $C$ difficle colitis was made. Other infectious causes of colitis were ruled out as stool sample was negative for diarrhoea producing bacterial pathogens and other ova and parasites. Considering the acuity and the clinical picture, inflammatory bowel disease was excluded. 


\section{TREATMENT}

Intravenous metronidazole and oral vancomycin along with vasopressor support in the form of intravenous fluids and dopamine was continued. Considering severe $C$ difficle infection with multiorgan system failure surgical colectomy was discussed, however declined by the patient's family. Considering the severe clinical picture and based on previous institutional experience IVIG was initiated. The patient received four doses of 30 grams IVIG on days 2 to 6 of hospitalisation.

\section{OUTCOME AND FOLLOW-UP}

Immediate effects were seen after the second dose with improvements in the white blood cell counts and the stool output. Also the patient's renal insufficiency improved and she was tapered off dopamine drip on day 3 of hospitalisation. The patient was extubated successfully on day 5 of hospitalisation. Patient's leucocytosis and diarrhoea completely resolved within a week of hospitalisation. Metronidazole and vancomycin were continued for 14 days and the patient was discharged from the hospital.

\section{DISCUSSION}

$C$ difficile pathogenic strains induce diarrhoea through the elaboration and secretion of two exotoxins namely, toxin $\mathrm{A}$ and toxin $\mathrm{B}$. Toxin $\mathrm{A}$ is an inflammatory toxin, leading to fluid secretion, increased mucosal permeability and marked enteritis and colitis. Toxin B is cytotoxic, leading to cell injury and apoptosis. ${ }^{4}$ The level of immune response to $C$ difficile colonisation is the major determinant of the severity of the disease. The first report describing use of IVIG for treatment of Clostridium infection in humans was published in $1991 .^{5}$ IVIG was used to treat five children with recurrent disease. These children were found to have significantly lower levels of IgG antitoxin A antibody as compared to healthy children. The authors reasoned that passively immunising the experimental group by transfusing antitoxin A IgG antibodies using IVIG would help in their recovery. All children receiving IVIG had clinical resolution of diarrhoea while on therapy.

Since then various small, mostly retrospective and nonrandomised reports have shown some success in using IVIG in the treatment of protracted, recurrent, or severe $C$ difficle infection. ${ }^{6}$ Diarrhoea resolution rates were higher; however the recurrence rates were similar. It is currently considered that the predominant mechanism of action for IVIG is through binding and neutralisation of toxin A by IgG antitoxin $\mathrm{A}$ antibodies. The mechanism of IgG antitoxin $\mathrm{A}$ antibody delivery to the lumen is unknown, however it is presumed to occur secondary to inflammation-induced mucosal damage. Further studies are needed before adopting IVIG as routine treatment for severe infection.

\section{Learning points}

- C difficile infection is the most common infectious cause of healthcare-acquired diarrhoea.

- C difficile pathogenic strains induce diarrhoea through the elaboration and secretion of two exotoxins namely, toxin $\mathrm{A}$ and toxin $\mathrm{B}$.

- Various small, mostly retrospective and nonrandomised reports have shown some success in using IVIG in the treatment of protracted, recurrent, or severe $C$ difficle infection.

- The predominant mechanism of action for IVIG is through binding and neutralisation of toxin $\mathrm{A}$ by $\lg \mathrm{G}$ antitoxin $\mathrm{A}$ antibodies.

\section{Competing interests None.}

Patient consent Obtained.

\section{REFERENCES}

1. Archibald LK, Banerjee SN, Jarvis WR. Secular trends in hospital-acquired Clostridium difficile disease in the United States, 1987-2001. J Infect Dis 2004;189:1585-9.

2. Bartlett JG. Narrative review: the new epidemic of Clostridium difficileassociated enteric disease. Ann Intern Med 2006;145:758-64.

3. Pépin J, Valiquette L, Alary ME, et al. Clostridium difficile-associated diarrhea in a region of Quebec from 1991 to 2003: a changing pattern of disease severity. CMAJ 2004;171:466-72.

4. Taylor NS, Thorne GM, Bartlett JG. Comparison of two toxins produced by Clostridium difficile. Infect Immun 1981;34:1036-43.

5. Leung DY, Kelly CP, Boguniewicz M, et al. Treatment with intravenously administered gamma globulin of chronic relapsing colitis induced by Clostridium difficile toxin. J Pediatr 1991:118(4 Pt 1):633-7.

6. Abougergi MS, Kwon JH. Intravenous immunoglobulin for the treatment of Clostridium difficile infection: a review. Dig Dis Sci 2011;56:19-26.

This pdf has been created automatically from the final edited text and images.

Copyright 2012 BMJ Publishing Group. All rights reserved. For permission to reuse any of this content visit http://group.bmi.com/group/rights-licensing/permissions.

BMJ Case Report Fellows may re-use this article for personal use and teaching without any further permission.

Please cite this article as follows (you will need to access the article online to obtain the date of publication).

Shahani L, Koirala J. Intravenous immunoglobulin in treatment of Clostridium difficile colitis. BMJ Case Reports 2012;10.1136/bcr.10.2011.5052, Published XXX

Become a Fellow of BMJ Case Reports today and you can:

- Submit as many cases as you like

- Enjoy fast sympathetic peer review and rapid publication of accepted articles

- Access all the published articles

- Re-use any of the published material for personal use and teaching without further permission

For information on Institutional Fellowships contact consortiasales@bmjgroup.com

Visit casereports.bmj.com for more articles like this and to become a Fellow

Keep up to date with all published cases by signing up for an alert (all we need is your email address) http://casereports.bmj.com/cgi/alerts/etoc 